\title{
Competencies Required of Engineering Students Conducting International Projects
}

Chetan S. Sankar, Auburn University, Auburn, USA

\begin{abstract}
Given the importance of students working in international environments, this study identifies the important competencies that engineering students need so that they could work effectively. The list of competencies was identified using a realist synthesis methodology. The context of the research was thirty-seven U.S. students who worked on twenty-two international projects with companies and research centers in India. The outcome was development of multi-media case studies based on the projects. The students spent a semester preparing for the project, eight weeks working on the project, and a semester developing the case studies. Each project was evaluated and students interviewed to identify the competencies that were utilized by the students. Analysis of these evaluations showed that successful projects trained the students to be competent in the technology domain of the project and encouraged them to communicate well with their counterparts.
\end{abstract}

\section{KEYWORDS}

Case Study Analysis, Collaboration, Competencies, Engineering, International Projects

\section{INTRODUCTION}

By 2050, 8.2 billion of the 9.2 billion people on Earth will live in developing countries, and economic growth in these countries is likely to equal or exceed that in the developed world (Lutz, Butz, \& Samir, 2015). At present, the U.S. economy is growing at a 1 to 2 percent rate, whereas the Indian and Chinese economies are each growing at 6 to 8 percent. Stephen D. Bechtel, Jr., the Chairman Emeritus and Director of Bechtel Group, Inc. (2006) states that "We must be able to manage and integrate globally constituted, multi-cultural teams that design and procure equipment, materials, and services internationally." Projects are expected to become even more complex, leading to a higher level of professionalism in project management, an increasing need for better governance of publicly funded projects, and more project-oriented organizations with higher levels of individual and organizational project management competencies (Schoper, Gemunden, \& Nguyen, 2016). Future engineering students, both in the US and other countries, need to know how to communicate effectively, think globally, be environmentally conscious, and appreciate the impact of social/cultural dynamics on a team environment in order to remain competitive in this kind of economic climate. A vital part of this process is for engineering educators to give their students opportunities to work on international projects (Jesiek, Zhu, Woo, Thompson, \& Mazzurco, 2014). Therefore, we formulate the research question: What are the important competencies that engineering students need so that they could work effectively on international projects?

\section{DOI: 10.4018/IJPMPA.20210701.oa}

This article published as an Open Access article distributed under the terms of the Creative Commons Attribution License (http://creativecommons.org/licenses/by/4.0/) which permits unrestricted use, distribution, and production in any medium, provided the author of the original work and original publication source are properly credited. 
Past research provides some guidelines in answering this question. A study based on a Delphi study of twelve subject matter experts developed a conceptual model that identified international contextual knowledge, global engineering preparedness, personal and professional qualities, and crosscultural and communications skills and strategies as the major elements that the experts considered important for success (Levonisova, Huang, Streiner, Cunningham, Ragusa, Besterfield-Sacre, \& Matherly, 2014). A wide-ranging literature review on engineering practice in global context finds that global engineering competency, technical coordination, engineering cultures, ethics, standards, and regulations are the most important competencies (Jesiek et al., 2014). A recent study identified 81 competencies and divided them across 11 dimensions (Rezende \& Blackwell, 2019; Dotsenko, Chumachenko, \& Chumachenko, 2019). But, none of these articles identify the important competencies required of engineering students who participate in international projects. This article addresses this gap in literature.

The next section provides further details on the potentially important competencies for international engineering education projects identified through a review of the literature. We then move on to discuss the methodology used in this research, describe the twenty-two international projects conducted during the period 2007 to 2013, and present the results of the data analysis. Finally, we discuss the findings and limitations of this study, and suggest possible directions for future research.

\section{LITERATURE REVIEW}

Even though there are many different definitions of competencies, the following two definitions are appropriate given the international nature of the projects analyzed in this paper. Competencies for project management can be defined as the knowledge, aptitudes, attitudes, and behaviors that are needed to carry out a piece of work that has a definite starting and end point (Boyatzis, 1982, 1996). Competency represents the ability to demonstrate appropriate behaviors in the application of relevant knowledge and skills in order to achieve effective performance in the context of a specific project (Hager \& Gonczi, 1996).

Many of the world's most pressing science and engineering challenges and opportunities are trans-national in nature, and the leading scientific and engineering facilities, resources, and expertise charged with investigating them are located around the globe. The National Science Foundation (NSF) urges universities to develop a globally-engaged STEM workforce that is capable of performing in an international research environment (NSF, 2015). We therefore searched for articles that discuss the competencies needed to conduct successful international collaborative projects.

In international conflict resolution (Tjosvold, Wan, \& Tang, 2016; Lewicki, Weiss, \& Lewin, 1992), an effective strategy is to employ third-party facilitators who help the parties reach a settlement. They might use mediation, arbitration, contextual knowledge, or other strategies to bring about resolution to issues that arise (Tjosvold et al., 2016; Lohr, Graef, Bonatti, Mahoo, Wambura, \& Sieber, 2017). Even though third-party facilitators provide strong assistance, participants in an international project need to have specific competencies.

We identify the specific competencies by performing a literature review (Table 1). This table lists the objectives of each study, identifies competency dimensions and maps them to competency items. When the authors found a large number of competency items, they created a few competency dimensions and then mapped them to the items.

The first study looked at students studying project management in South Africa and the United Kingdom. Compared with their peers in the United Kingdom, students in South Africa reported higher levels of overall experience and usage of online learning materials and lower levels of blended learning and individual critical evaluation skills. They recommended that future studies seek to understand the competencies that impact learning experiences when the students perform projects across different countries (Ojiako, Chipulu, Marshall, Ashleigh, \& Williams, 2015). 
Table 1. Literature review of articles that identify competencies of international project teams

\begin{tabular}{|c|c|c|c|}
\hline $\begin{array}{l}\text { Ojiako, Chipulu, } \\
\text { Marshall, } \\
\text { Ashleigh, \& } \\
\text { Williams (2015) }\end{array}$ & $\begin{array}{l}\text { A comparative analysis of } \\
\text { students' experiences and } \\
\text { expectations between } \\
\text { South Africa and United } \\
\text { Kingdom }\end{array}$ & $\begin{array}{l}\text { - Overall experience } \\
\text { - Usage of online learning materials } \\
\text { - Critical evaluation skills }\end{array}$ & $\begin{array}{l}\text { Mapped to } \\
\text { Competency } \\
\text { Items } \\
\text { Not discussed }\end{array}$ \\
\hline $\begin{array}{l}\text { Briere, Proulx, } \\
\text { Flores, \& Laporte } \\
\text { (2015) }\end{array}$ & $\begin{array}{l}\text { What are the competencies } \\
\text { of project managers in } \\
\text { international development } \\
\text { NGOs? }\end{array}$ & $\begin{array}{ll}\text { - } & \text { Adaptability } \\
\text { - } & \text { Knowledge set } \\
\text { - } & \text { Communications } \\
\text { - } & \text { Interpersonal qualities } \\
\text { - } & \text { Leadership } \\
\text { - } & \text { Ethics } \\
\text { - } & \text { Cacal network } \\
\text { - Chacity building } & \text { Change management }\end{array}$ & Not discussed \\
\hline $\begin{array}{l}\text { Ortiz-Marcos, } \\
\text { Cobo Benita, } \\
\text { Aldeanueva, \& } \\
\text { Colsa (2013) }\end{array}$ & $\begin{array}{l}\text { What competencies are the } \\
\text { most relevant in managing } \\
\text { international cooperation } \\
\text { engineering projects? }\end{array}$ & $\begin{array}{l}\text { - Integration management } \\
\text { - Scope management } \\
\text { - Orientation toward achieving results } \\
\text { - Initiative and problem solving } \\
\text { - Cooperative teamwork }\end{array}$ & Not disucssed \\
\hline $\begin{array}{l}\text { Jesiek, Znu, Woo, } \\
\text { Thompson, \& } \\
\text { Mizzurco (2014) }\end{array}$ & $\begin{array}{l}\text { Literature review of } \\
\text { engineering competencies } \\
\text { in a global context }\end{array}$ & $\begin{array}{l}\text { - } \quad \text { Technical coordination } \\
\text { - Understanding and negotiating engineering cul tures } \\
\text { - Navigating e thics, standards, and regulations }\end{array}$ & Not discussed \\
\hline $\begin{array}{l}\text { Rezende and } \\
\text { Blackwell (2019) }\end{array}$ & $\begin{array}{l}\text { Develop a competency } \\
\text { framework }\end{array}$ & $\begin{array}{l}\text { - } \text { Influencing } \\
\text { - }\end{array}$ & $\begin{array}{l}\text { Mapped to } 81 \\
\text { competencies }\end{array}$ \\
\hline $\begin{array}{l}\text { Levonisova, } \\
\text { Huang, Streiner, } \\
\text { Cunningham, } \\
\text { Ragusa, } \\
\text { Besterfield-Sacre, } \\
\text { Shuman, \& } \\
\text { Matherly (2014) }\end{array}$ & $\begin{array}{l}\text { What are the essential } \\
\text { characteristics, skills, and } \\
\text { strategies associated with } \\
\text { engineering global } \\
\text { preparedness? }\end{array}$ & $\begin{array}{l}\text { - Global prepare dness } \\
\text { - } \quad \text { Personal and professional qualities } \\
\text { - Cross-cultural communication skills \& strategies }\end{array}$ & $\begin{array}{l}\text { Mapped to } 31 \\
\text { competencies }\end{array}$ \\
\hline
\end{tabular}

The second study investigated the competencies of project managers in international nongovernmental organizations, identifying 11 competencies, of which ten were related to human aspects, namely adaptability, knowledge set, communications, personal qualities, interpersonal skills, leadership, ethics, local network, capacity building, and change management (Brière, Proulx, Flores, \& Laporte, 2015).

Authors of the third study interviewed 51 project managers with international experience in development organizations, who identified the weakness of the link between the financial backers and the end receivers of the service, the lack of appreciation for the quality of the service offered, and the intangible nature of human development-linked objectives as the major challenges they face in the course of their work (Ortiz-Marcos, Cobo-Benita, Aldeanueva, \& Colsa, 2013). 
The fourth study performed a literature review that identified technical coordination, understanding engineering cultures, and navigating ethics, standards, and regulations as critical competencies (Jesiek et al., 2014).

The fifth study systematically analyzed the literature to develop a competency framework. They identified 11 dimensions (influencing, communication, emotional, contextual, management, cognitive skills, professionalism, knowledge and experience, project management knowledge, personal skills and attributes) and mapped 81 competencies to these dimensions. Research on project management competency was explored from different perspectives, leading to discussions focused on specific topics such as leadership, emotional intelligence, general and project management competencies, among few others (Verma, 1996; Barker, 2014; Marsino, 2013; Boyatzis, Stubbs, \& Taylor, 2002; Wiek, Withycombe, \& Redman, 2011). They also developed a competency assessment instrument that could be used by educators.

The sixth study conducted a research summit for a group of subject matter experts in engineering and international education, seeking to reach a consensus on the competencies required of globally prepared engineering students. The experts defined global preparedness as the readiness to engage and operate effectively under uncertainty in different cultural contexts when addressing engineering problems. They used a three-round Delphi process and a series of face-to-face meetings to identify four major dimensions of competencies: international contextual knowledge, global engineering preparedness, personal and professional qualities, and cross-cultural communication skills and strategies. These four dimensions were mapped to a total of 31 items (Levonisova et al., 2014).

Despite the diversity and number of competencies reported in these studies, research on the impact of these competencies on students' actual preparedness to step into the global workforce has been limited. Project managers who lead student project teams do not get any guidance from these articles on which competencies are important. Without such information, it is difficult to select and train the students who have the potential to perform successful international projects. Thus, there is a gap in literature that investigates the specific competencies of engineering students who participate in international projects.

\section{METHODOLOGY}

In order to fill this gap in literature, our research employed the Realist Synthesis (Pawson, 2006) methodology. This methodology is underpinned by a 'generative' understanding of causation, which holds that, to infer a casual outcome/relationship between an intervention and an outcome $(\mathrm{O})$ of interest, one needs to understand the underlying mechanisms (M) that connect them and the context (C) in which the relationship occurs (Gough, Oliver, \& Thomas, 2012, p. 43). In this research, the context (C) was where the researcher was the principal investigator of two grants which funded U.S. students to conduct twenty-two international projects during 2007-2013 in India. The students collaborated with Indian engineers/ students and conducted the projects in two research laboratories and three companies. The outcome $(\mathrm{O})$ was that each student team completed the project by developing a multi-media case study that was approved by the research laboratory/ company as depicting the problem, alternatives considered, and the implemented solutions. These case studies were designed to showcase the use of theory learned in classrooms to solve the practical problems faced by these engineers. The mechanism (M) adopted by the research was that the students spent a semester preparing for the project, eight weeks working in India, and a semester analyzing the results and developing a case study. Thereby, each student worked for a year on this project and actively participated in the initiating, planning, executing, monitoring, controlling, and closing processes of the projects.

Realist synthesis methodology using interviews and questionnaires was chosen for three primary reasons: (1) qualitative research methods are most suited to understanding the tentative connections between the required competencies and the outcomes, (2) the findings can contribute to building an emerging theory based on the data rather than reflect previously held theories, and (3) there is 
little known about the competencies required for engineering students to succeed in performing international projects (Collyer, 2017).

The methodology involved the researcher reading and rereading of the textual representation of the data closely (the case study developed by the student teams) and identifying potentially relevant data and their interrelationships. In addition, we developed and executed an open-ended questionnaire that asked the students about the competencies they felt were critical in conducting these projects after they have completed the projects. We also interviewed them as well as the project sponsors at the end of each project to identify whether the project was perceived to be successful or not in achieving its intended objectives.

As part of the realist synthesis methodology, we compared our results with the literature review to identify whether any of the past research can explain how and why these projects were either successful or unsuccessful. We developed a flowchart that utilizes the categories of international contextual knowledge, global engineering preparedness, personal and professional qualities, crosscultural communications skills and strategies provided by Levonisova et al. (2014).

In order to classify how well each project was conducted according to these categories, we used the nominal group technique (PMBOK Guide, 2017) where the researchers, students, evaluators, and the sponsors of the project discussed each project and classified the importance of the four competencies as either low, medium, or high in that project. A low classification states that a particular competency was not perceived to be that critical by the students, managers, and sponsors in conducting that project. A high classification implies a competency was perceived to be most critical by the students, managers, and sponsors in conducting that project. A medium classification states that it was perceived to be moderately important in conducting the project.

\section{PROJECTS}

The twenty-two projects were conducted using the waterfall methodology in a number of different host organizations, including a leading construction company, a federal research laboratory, two university research centers, and a high-pressure boiler plant, all in India. These projects covered a wide range of topics and disciplines. The project hired an international student from India studying at the same U.S. University as the participants to coordinate the project on a day-to-day basis. This third-party facilitator strategy was extremely helpful, since participating students had difficulty in daily activities such as obtaining phones/ money/ hiring taxis without active help in the first few weeks of arriving in India. Table 2 summarizes the objective of each project, the number of students who participated in it, their majors, deliverables for the project and the benefit received or not received by the sponsor.

\section{RESULTS}

The documents that were collected on these projects, interview records, and sponsor feedback were analyzed using the categories outlined by Levonisova et al. (2014) and the results are shown in Table 6 in the Appendix. This Appendix shows that the sponsors considered 17 of the 22 projects successful. For each project, the extent of use of international contextual knowledge, global engineering preparedness, personal and professional qualities, and cross-cultural communication skills and strategies to complete the project was evaluated using the nominal group technique (PMBOK Guide, 2017) and ranked as low, medium, or high importance.

The students were also asked to complete a questionnaire at the end of their project, with the results shown in Table 3. We classified the answers provided by the students according to the four categories. The students generally felt technically prepared to work on the projects and showed sufficient personal and professional skills, but did not feel proficient in crosscultural communications. 


\section{Table 2. Summary of projects}

\begin{tabular}{|c|c|c|c|c|}
\hline Project & $\begin{array}{l}\text { Number of } \\
\text { Students and } \\
\text { majors }\end{array}$ & Objective & $\begin{array}{l}\text { Deliverable for } \\
\text { the project }\end{array}$ & $\begin{array}{l}\text { Benefit to } \\
\text { sponsor }\end{array}$ \\
\hline $\begin{array}{l}1-\text { Data } \\
\text { Synchronization } \\
\text { project }\end{array}$ & $\begin{array}{l}1 ; \text { computer } \\
\text { science }\end{array}$ & $\begin{array}{l}\text { Synchronize data between a } \\
\text { remote area and } \\
\text { headquarters for a } \\
\text { construction company }\end{array}$ & $\begin{array}{l}\text { Software } \\
\text { developed in C+ }\end{array}$ & $\begin{array}{l}\text { Integrated into } \\
\text { operational } \\
\text { system; Published }\end{array}$ \\
\hline $\begin{array}{l}2 \text { - Thermal Comfort } \\
\text { Projed }-1\end{array}$ & $\begin{array}{l}\text { 1; architecture } \\
\text { 1; Indian } \\
\text { doctoral } \\
\text { candidate }\end{array}$ & $\begin{array}{l}\text { Conduct thermal comfort } \\
\text { analysis of two residential } \\
\text { structures }\end{array}$ & A report & $\begin{array}{l}\text { Report not found } \\
\text { to be valuable }\end{array}$ \\
\hline $\begin{array}{l}\text { 3- Thermal Comfort } \\
\text { Projed - II }\end{array}$ & $\begin{array}{l}\text { 2; construction } \\
\text { management } \\
\text { and economics }\end{array}$ & $\begin{array}{l}\text { Evaluate performance } \\
\text { (technical and cost) of four } \\
\text { different materials: solid } \\
\text { concrete, hollow blocks, solid } \\
\text { blocks, and clay bricks for } \\
\text { thermal comfort properties } \\
\end{array}$ & $\begin{array}{l}\text { Report and } \\
\text { recommendation } \\
\text { to company }\end{array}$ & $\begin{array}{l}\text { Report highly } \\
\text { valued and } \\
\text { integrated into } \\
\text { company } \\
\text { practices }\end{array}$ \\
\hline $\begin{array}{l}4 \text {-Thermal Comfort } \\
\text { Projed - III }\end{array}$ & $\begin{array}{l}\text { 2; Civil } \\
\text { Engineering } \\
\text { and } \\
\text { Architecture }\end{array}$ & $\begin{array}{l}\text { Develop an introductory } \\
\text { course material that shows } \\
\text { the importance of thermal } \\
\text { comfort in Southern Indian } \\
\text { and central Alabama }\end{array}$ & $\begin{array}{l}\text { Case study to } \\
\text { academic } \\
\text { sponsors }\end{array}$ & $\begin{array}{l}\text { Accepted as of } \\
\text { high quality }\end{array}$ \\
\hline $\begin{array}{l}\text { 5. Thermal Comfort } \\
\text { Projed -IV }\end{array}$ & $\begin{array}{l}2 ; \text { graphic } \\
\text { design and } \\
\text { industrial } \\
\text { engineering }\end{array}$ & $\begin{array}{l}\text { Develop an Internet portal } \\
\text { that a company's architects } \\
\text { could use to obtain climate- } \\
\text { related data depending on the } \\
\text { location of new buildings }\end{array}$ & $\begin{array}{l}\text { Software that } \\
\text { integrated data } \\
\text { collected in } \\
\text { earlier projects } \\
\text { with company's } \\
\text { requirements }\end{array}$ & $\begin{array}{l}\text { Accepted and } \\
\text { integrated into } \\
\text { operational } \\
\text { software }\end{array}$ \\
\hline $\begin{array}{l}\text { 6. Thermal Comfort } \\
\text { Projed }-V\end{array}$ & $\begin{array}{l}2 \text {; industrial } \\
\text { engineering } \\
\text { and MIS }\end{array}$ & $\begin{array}{l}\text { Design a decision support } \\
\text { tool that predicts annual } \\
\text { cooling loads for a range of } \\
\text { glass-frame-shade } \\
\text { combinations }\end{array}$ & Software & $\begin{array}{l}\text { Accepted and } \\
\text { integrated into } \\
\text { operational } \\
\text { software }\end{array}$ \\
\hline $\begin{array}{l}\text { 7. Design of } \\
\text { Buildings - I }\end{array}$ & $\begin{array}{l}\text { 2; civil } \\
\text { engineering } \\
\text { and computer } \\
\text { engineering } \\
\text { plus } 3 \text { Indian } \\
\text { students }\end{array}$ & $\begin{array}{l}\text { Compare design of two } \\
\text { dormitories on a university } \\
\text { campus on their thermal } \\
\text { comfort and social use of } \\
\text { spaces }\end{array}$ & Case study & $\begin{array}{l}\text { Accepted by } \\
\text { academic sponsor }\end{array}$ \\
\hline $\begin{array}{l}\text { 8. Design of } \\
\text { Buildings - ॥ }\end{array}$ & $\begin{array}{l}2 \text {; industrial } \\
\text { design and } \\
\text { building } \\
\text { science }\end{array}$ & $\begin{array}{l}\text { Compare thermal comfort of } \\
\text { apartments built in the cities } \\
\text { of Bangalore and New Delhi }\end{array}$ & $\begin{array}{l}\text { Sofware that } \\
\text { predicted thermal } \\
\text { comfort of } \\
\text { apartments } \\
\end{array}$ & $\begin{array}{l}\text { Integrated into } \\
\text { company's } \\
\text { software }\end{array}$ \\
\hline $\begin{array}{l}\text { 9. Auditorium } \\
\text { acoustic reflector } \\
\text { design }\end{array}$ & $\begin{array}{l}2 \text {; industrial } \\
\text { design and } \\
\text { polymer } \\
\text { sciences }\end{array}$ & $\begin{array}{l}\text { Create an aesthetically } \\
\text { pleasing reflector design that } \\
\text { uses natural materials and } \\
\text { does not require connection } \\
\text { to a power grid }\end{array}$ & Case study & $\begin{array}{l}\text { Accepted by } \\
\text { academic } \\
\text { sponsors and } \\
\text { published }\end{array}$ \\
\hline $\begin{array}{l}\text { 10. Develop a Life } \\
\text { Cycle Cost System }\end{array}$ & $\begin{array}{l}\text { 3; industrial } \\
\text { design, interior } \\
\text { design, \& } \\
\text { management }\end{array}$ & $\begin{array}{l}\text { Develop a decision support } \\
\text { tool that computes Ife cycle } \\
\text { cost analysis for different } \\
\text { HVAC sy stems }\end{array}$ & Software & $\begin{array}{l}\text { Considered } \\
\text { inadequate and } \\
\text { not accepted }\end{array}$ \\
\hline $\begin{array}{l}\text { 11. Non-destructive } \\
\text { testing of oil tanks }\end{array}$ & $\begin{array}{l}\text { 2; electrical } \\
\text { engineering }\end{array}$ & $\begin{array}{l}\text { Use either wired or wireless } \\
\text { data acquisition sensors in oil } \\
\text { tanks }\end{array}$ & $\begin{array}{l}\text { Develop a } \\
\text { prototype }\end{array}$ & $\begin{array}{l}\text { Accepted by the } \\
\text { academic spons or }\end{array}$ \\
\hline $\begin{array}{l}\text { 12. Automated weld } \\
\text { inspection }\end{array}$ & $\begin{array}{l}\text { 1; Mechanical } \\
\text { engineering }\end{array}$ & $\begin{array}{l}\text { Develop algorithm to detect } \\
\text { defects in welds by analyzing } \\
\text { radiographs }\end{array}$ & Algorithm & $\begin{array}{l}\text { Accepted by } \\
\text { academic sponsor }\end{array}$ \\
\hline $\begin{array}{l}\text { 13. Laser } \\
\text { Ultrasonics - I }\end{array}$ & $\begin{array}{l}\text { 1; Mechanical } \\
\text { engineering }\end{array}$ & $\begin{array}{l}\text { Install a dass } 4 \text { laser safely } \\
\text { on an aluminum tank }\end{array}$ & Installation & $\begin{array}{l}\text { Accepted by } \\
\text { academic } \\
\text { sponsor }\end{array}$ \\
\hline $\begin{array}{l}\text { 14. Laser } \\
\text { Uitrasonics - II }\end{array}$ & $\begin{array}{l}\text { 1; Mechanical } \\
\text { engineering }\end{array}$ & $\begin{array}{l}\text { Develop an online manual } \\
\text { that describes how to use the } \\
\text { laser }\end{array}$ & Online manual & $\begin{array}{l}\text { Not accepted } \\
\text { by the } \\
\text { academic } \\
\text { sponsor }\end{array}$ \\
\hline $\begin{array}{l}\text { 15. Develop an } \\
\text { Impact Echo } \\
\text { prototype }\end{array}$ & $\begin{array}{l}\text { 2; Mechanical } \\
\text { engineering \& } \\
\text { MIS }\end{array}$ & $\begin{array}{l}\text { Design an impact echo } \\
\text { prot otype that evaluates } \\
\text { structural integrity of various } \\
\text { concrete structures }\end{array}$ & $\begin{array}{l}\text { Design document } \\
\text { and case study }\end{array}$ & $\begin{array}{l}\text { Accepted by } \\
\text { academic } \\
\text { sponsor }\end{array}$ \\
\hline $\begin{array}{l}\text { 16. Solar panel } \\
\text { design and } \\
\text { installation }\end{array}$ & $\begin{array}{l}\text { 2; Mechanical } \\
\text { engineering } \\
\text { students \& a } \\
\text { research } \\
\text { center }\end{array}$ & $\begin{array}{l}\text { Design and implement a solar } \\
\text { power unit for a non- } \\
\text { governmental organization in } \\
\text { a rural village in India }\end{array}$ & $\begin{array}{l}\text { Design and } \\
\text { implementation }\end{array}$ & $\begin{array}{l}\text { Successfully } \\
\text { designed and } \\
\text { implemented; } \\
\text { operational }\end{array}$ \\
\hline 17. Handbag design & $\begin{array}{l}\text { 1; Consumer } \\
\text { and design } \\
\text { sciences }\end{array}$ & $\begin{array}{l}\text { Design and prototype a } \\
\text { handbag that could be sold } \\
\text { via Fair Trade Organizations }\end{array}$ & $\begin{array}{l}\text { Design and } \\
\text { prototype }\end{array}$ & $\begin{array}{l}\text { Accepted by } \\
\text { academic } \\
\text { sponsor, } \\
\text { published }\end{array}$ \\
\hline $\begin{array}{l}\text { 18. Design an } \\
\text { Automated } \\
\text { Inspection Trolley }\end{array}$ & $\begin{array}{l}\text { 2; Mechanical } \\
\text { engineering }\end{array}$ & $\begin{array}{l}\text { Design a trolley that could be } \\
\text { used to inspect rails using } \\
\text { non-destructive } \\
\text { methodologies }\end{array}$ & Design & $\begin{array}{l}\text { Accepted by } \\
\text { academic } \\
\text { sponsor }\end{array}$ \\
\hline $\begin{array}{l}\text { 19. Develop a cross- } \\
\text { cultural } \\
\text { communications } \\
\text { game }\end{array}$ & $\begin{array}{l}\text { 2; } \\
\text { Communicatio } \\
\text { ns; Psychology }\end{array}$ & $\begin{array}{l}\text { Develop a game that could be } \\
\text { used to train other students } \\
\text { on communications aspects } \\
\text { when engaged in } \\
\text { international projects }\end{array}$ & $\begin{array}{l}\text { Develop script } \\
\text { and test }\end{array}$ & $\begin{array}{l}\text { Field trial } \\
\text { showed that } \\
\text { lacked } \\
\text { engineering } \\
\text { content }\end{array}$ \\
\hline $\begin{array}{l}\text { 20. Develop an } \\
\text { accounting } \\
\text { information system }\end{array}$ & 1; Accounting & \begin{tabular}{|l|} 
Develop an accounting \\
information sy stem for a small \\
company \\
\end{tabular} & $\begin{array}{l}\text { Implementation } \\
\text { of software }\end{array}$ & $\begin{array}{l}\text { Accepted by } \\
\text { sponsor }\end{array}$ \\
\hline $\begin{array}{l}21 . \text { Develop a } \\
\text { business plan }\end{array}$ & $\begin{array}{l}\text { 2; MIS, Public } \\
\text { administration }\end{array}$ & $\begin{array}{l}\text { Develop a business plan for a } \\
\text { small company }\end{array}$ & $\begin{array}{l}\text { Development of } \\
\text { business plan }\end{array}$ & $\begin{array}{l}\text { Not accepted } \\
\text { by sponsor }\end{array}$ \\
\hline $\begin{array}{l}\text { 22. Document a } \\
\text { telemedicine system }\end{array}$ & $\begin{array}{l}2 ; \text { biomedical } \\
\text { sciences \& } \\
\text { veterinary } \\
\text { medicine } \\
\end{array}$ & $\begin{array}{l}\text { Document a telemedicine } \\
\text { system used by research } \\
\text { laborat ory }\end{array}$ & $\begin{array}{l}\text { Develop case } \\
\text { study }\end{array}$ & $\begin{array}{l}\text { Accepted by } \\
\text { sponsor; } \\
\text { Published }\end{array}$ \\
\hline
\end{tabular}


Table 3. Students' perceptions of required competencies to implement their projects

\begin{tabular}{lc} 
Required Competencies & $\begin{array}{c}\text { Mean } \\
\text { (n=30) }\end{array}$ \\
\hline Contextual Kn owedge & 3.07 \\
Our class meetings prepared me for research in India & 3.27 \\
I had a clear understanding of what was expected & 2.40 \\
I previously had the opportunity to work/ study in a culture other than my own & \\
& \\
Engin eering Preparedness & 3.93 \\
The experience offered me an opportunity to apply the theory I had learned to develop a & \\
research project & 4.20 \\
\hline $\begin{array}{l}\text { Personal \& Professional Qualities } \\
\text { The experience helped develop my ability to analyze, evaluate, and create, when working with }\end{array}$ & 4.17 \\
new ideas or solving problems & \\
This experience dev eloped my leadership skills & 2.45 \\
\hline Cross-cultural communication skills \& Strategies \\
While in India, I was able to complete my project without building cross-cultural skills (negative \\
question)
\end{tabular}

The students provided additional comments in the focus group sessions and these are shown, along with comments provided by the industry and academic partners about the capability of the students, in Table 4.

\section{ANALYSIS OF THE RESULTS}

Most of the students had sufficient global engineering preparedness since they were students majoring in a discipline and were either senior undergraduate or graduate students. They were

Table 4. Comments provided by students/managers/sponsors

\begin{tabular}{|c|c|}
\hline Required Competencies & Student/ Manager/ Sponsor Comments \\
\hline Contextual Knowedge & $\begin{array}{l}\text { - A teacher stated, "I can see a real difference in the student's attitude } \\
\text { and motivation in my research laboratory after his return. He has made } \\
\text { a significant step from being a student to being an engineer." } \\
\text { - I had to expect the un expected during the project. } \\
\text { - Lack of preparation for the reality of India } \\
\text { - Expectations were different }\end{array}$ \\
\hline Engineering Preparedness & $\begin{array}{l}\text { - I sharpened my strength in technical research by working with non- } \\
\text { destructive laboratory } \\
\text { - When the research environments in the U.S. and India were similar, } \\
\text { students succeeded in projects; when it was different, projeds failed. } \\
\text { - Working on a problem in my major was excellent }\end{array}$ \\
\hline $\begin{array}{l}\text { Personal and Professional } \\
\text { skills }\end{array}$ & $\begin{array}{l}\text { - Overall experience makes you good in living and working in a foreign } \\
\text { country. } \\
\text { - } \quad \text { Being able to work at my own pace and schedule, I gained confidence. } \\
\text { - Conducting research in a developing country has greatly improved my } \\
\text { - There was a need for high mutual dependence and trust among the } \\
\text { participants for the project to succeed. } \\
\text { - Taught me real-world problem solving abilities and life skills } \\
\text { - Wewitnessed good thought process and good grasp of the situation. }\end{array}$ \\
\hline $\begin{array}{l}\text { Cross-cultural } \\
\text { communication skills \& } \\
\text { strategies }\end{array}$ & $\begin{array}{l}\text { - We talked with the executives about India, the U.S., globalization and } \\
\text { howthe world was changing. It was amazing. } \\
\text { - The most important part of the trip was cooperation between people } \\
\text { from different cultures who spoke different languages. } \\
\text { - We had differences of opinion about the technical aspect of the work } \\
\text { versus making it understandable and useable. } \\
\text { - We were exposed to an extremely different style of life than the one we } \\
\text { are used. } \\
\text { - I feel my communication skills benefited greatly } \\
\text { - Working in a completely different culture has broadened my view of the } \\
\text { - Eorld } \\
\text { Encountering a dense population that adopts differently } \\
\text { Observing the difference in how people acknowledge each other, for } \\
\text { example nodding heads }\end{array}$ \\
\hline
\end{tabular}


well versed in problem solving since their academic preparation focused on it. The students also perceived that they were well-prepared as shown in Table 3 (score close to 4) and Table 4. When we analyzed the projects that failed, we noticed that the students' preparation in the technical discipline that was needed in the project was either low or medium. Students whose global engineering preparedness was high led successful projects. Therefore, we consider this to be a critical competency.

The students perceived that their cross-cultural communication skills and strategies were rather low (score of 2.45) as indicated in Tables 3 and 4. The students had difficulty working in a different culture that treats time differently and uses different visual clues. As Table 4 shows, no team had high cross-cultural communication skills and strategies since none of them had much exposure to that culture. But, the projects that failed always had students with low cross-cultural communication skills and strategies. Therefore, we consider this to be another important competency.

The students perceived that their personal and professional qualities were well suited to the projects as indicated by the scores above 4 in Table 3 and positive comments in Table 4 . The students were selected based on their majors and their ability to contribute to the projects. But, it did not prevent some of their projects to fail. Therefore, we consider this to be another important competency.

The international contextual knowledge was uniformly neutral (close to 3 ) for most of the students as shown in the scores in Table 3 and comments in Table 4. Surprisingly, when we had a few students who had visited India earlier or their parents were from that region (projects 10, 14 and 19), these projects still failed. In contrast, projects where students had very low international contextual knowledge (some of the students had not even traveled outside the Southeastern US where the University was located) succeeded and the deliverables were incorporated in the sponsor's product offerings.

\section{Findings}

We developed a flowchart (Figure 1) based on the results of the project. After the project was started in India, a third-party facilitator (a graduate student of Indian origin studying in the same Southeastern U.S. university as the students) was available continuously during the two-month period for all projects; this assured that students struggling with international contextual knowledge could resolve them with the help of the third-party facilitator. When we started the projects, we were concerned that the students lacked contextual knowledge about India and devoted several sessions to teaching them about the country. However, this only helped to a limited extent since the culture shock was present from the moment they landed in Chennai, India. Even though they had seen YouTube videos of the city and its environment, the contextual knowledge was only obtained after they arrived in the city when the reality hit them. Therefore, we limited preparing them for the Indian context in the later projects and encouraged them to use the third-party facilitator to obtain contextual knowledge. This result is corroborated by the findings of Bartel-Radic, Moos, \& Long (2015) and Sankar, Raju, \& Clayton (2009) who found that travel experience, living abroad, and foreign language proficiency did not correlate significantly with multinational team interactions.

The second diamond in the flowchart shows that global engineering preparedness was an important competency. Those students who had the appropriate educational background or a strong interest in the project generally completed it successfully. Projects of students who did not feel they had the appropriate engineering preparedness did not succeed. When they felt prepared, they were able to overcome the other difficulties involved in conducting the projects since they understood the problem and were able to work actively with their Indian partners to resolve them. This finding confirms with Brière et al.'s (2015) research, which ranked project management skills such as meeting deadlines and budgets as equally important to technical competency. The finding agrees with Ojiako et al. (2015) who state that learning approaches of students were more dependent on context-specific factors than on natural culture differences, reporting that the perceived strategic importance of engineering as a profession to South African students seems to have a positive and encouraging impact on their overall learning experiences. 
Figure 1. Flowchart depicting competencies displayed in successful projects

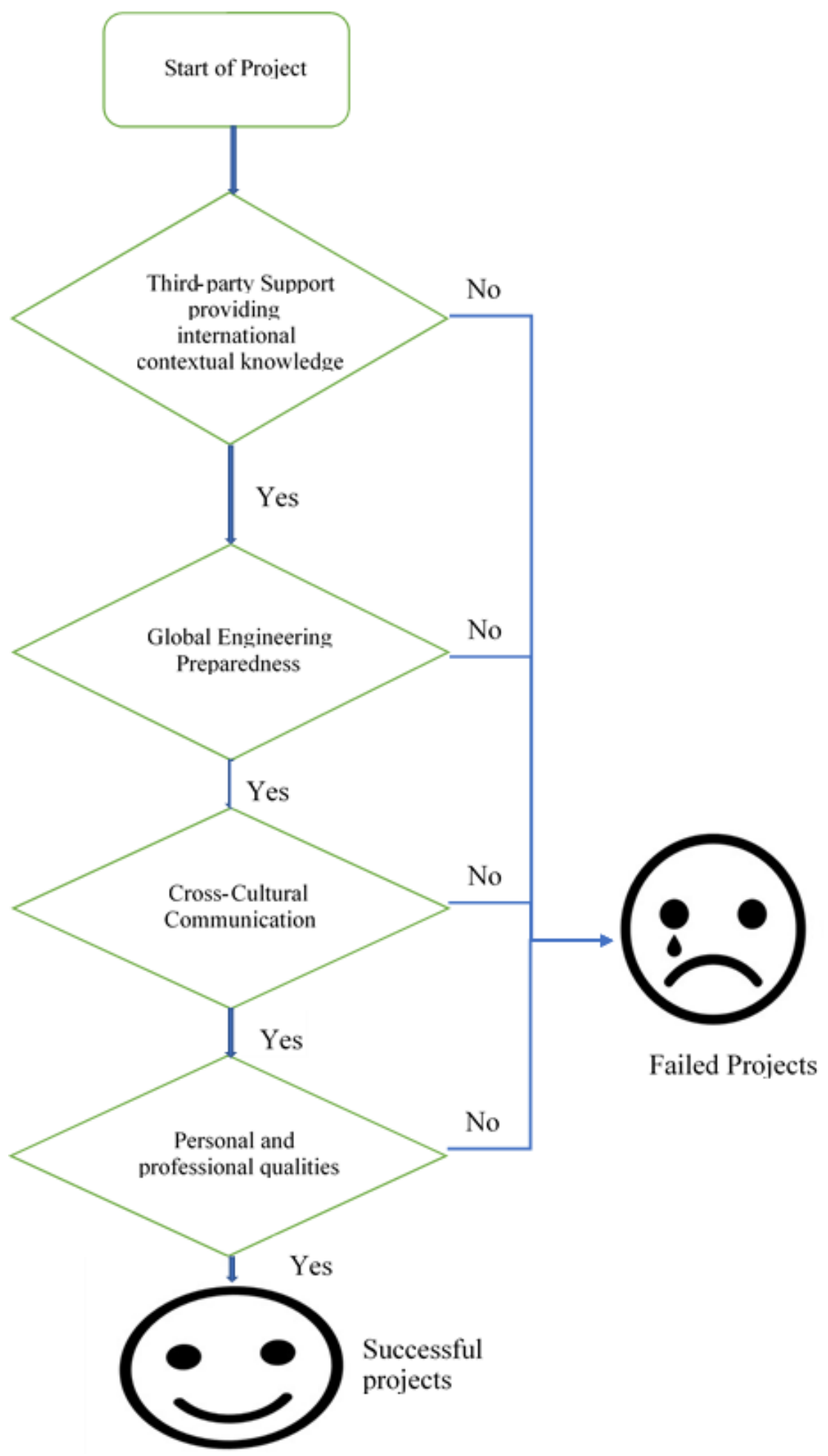


The third diamond in the flowchart highlights the importance of cross-cultural communication skills. Ojiako et al. (2015) also note that in addition to professional competency, international students place increasing emphasis on holistic knowledge and learning, leading to our finding, which is that cross-cultural communication skills and strategies are critical for technical/ engineering students. Even though many students were prepared well for the technical/ engineering aspects of their project, a major reason for delay/ failure was difficulties with cross-cultural communication skills. Some students were simply not able to cope with the new culture and had to be coached constantly by the third-party facilitator. This result is corroborated by Bartel-Radic et al. (2015), who suggest that students with higher intercultural competence work more easily and effectively in global teams. Ortiz-Marcos et al. (2013) agree, highlighting a need for continuous adaptation to the environment in international cooperation projects. Brière et al. (2015) concur, stressing the need to adapt to the reality of the situation as a critical competency, while Dillon \& Taylor (2015) contend that internal and external communication is the highest ranked category (explaining $28 \%$ of the incidents) in their study of project managers. They also found that more experienced managers had greater communication competencies, whereas less experienced managers relied more on control categories. Eskerod (2010) suggests that social confidence, perceived credibility, and perceived trustworthiness are critical competencies that help international projects succeed. It is possible that those students who were more proficient in cross-cultural communication were able to project themselves better, thereby creating a more trusting environment in which to conduct their projects.

The fourth diamond in the flowchart highlights the importance of personal and professional qualities. Even though this competency is important, the students who opted to work on these projects were highly motivated and willing to explore new projects/ countries/ opportunities. Therefore, this was not a difficult issue for these students. Self-management abilities such as the ability to work in harsh field conditions were also mentioned by several respondents in Brier et al. (2015)'s survey.

We found that the realist synthesis methodology helped us conceptualize the research using the context $(\mathrm{C})$, mechanism $(\mathrm{M})$, and Outcome $(\mathrm{O})$ framework. We wanted to investigate whether this methodology might explain the results of joint student projects conducted in other countries using a literature review. Therefore, Table 5 was developed based on applying the methodology to four other studies. These studies show that the results of the study differ based on the context and expected outcomes. These results further strengthen our use of realist synthesis methodology to analyze these projects.

\section{IMPLICATIONS}

The results of the study have implications for funding agencies, students, sponsors of international projects, engineers, and professionals. Many agencies such as the NSF, the Fulbright Scholar Program, and the Peace Corps encourage international travel and work for students and scholars. The findings from this study could be helpful to such funding agencies in developing appropriate criteria for selecting candidates for international projects. They may also need to recognize the need for funding third-party facilitators so that they can help the students in coping with differing context and communication requirements.

Those students and scholars who embark on international projects may also benefit from reading the findings of this study, which highlight the need for them to become technically proficient and make them aware that they will face major cross-cultural communication issues (Sutcliffe, Chan, \& Nakayama, 2020). Extensive preparation on the engineering aspects may facilitate their adaptation to their unfamiliar environment and provide them with more fruitful engagements in their host countries. An encouraging result is that the study shows that students who undertake international projects need not have prior international experiences for the project to succeed provided an appropriate third-party facilitator is available to facilitate the projects. Even if they were unaware of the cultural heritage of 
Table 5. Results of applying realist synthesis methodology to research articles

\begin{tabular}{|c|c|c|c|c|}
\hline Study & Context (C) & Mechanism (M) & Outcome (O) & Results \\
\hline $\begin{array}{l}\text { Daniels, } \\
\text { Cajander, Clear, } \\
\text { \& McDermott } \\
\text { (2015): U.S. - } \\
\text { Sweden }\end{array}$ & $\begin{array}{l}\text { English-speaking } \\
\text { students } \\
\text { working in a } \\
\text { English-speaking } \\
\text { company on } \\
\text { projects related } \\
\text { to their majors }\end{array}$ & $\begin{array}{l}\text { Summer } \\
\text { internships and } \\
\text { subsequent } \\
\text { documentation }\end{array}$ & $\begin{array}{l}\text { Success or } \\
\text { failure of project } \\
\text { as assessed by } \\
\text { sponsors }\end{array}$ & $\begin{array}{l}\text { Global } \\
\text { engineering } \\
\text { preparedness, } \\
\text { cross-cultural } \\
\text { communication } \\
\text { skills, contextual } \\
\text { knowledge, } \\
\text { personal and } \\
\text { professional } \\
\text { abilities, and } \\
\text { third-party } \\
\text { facilitator } \\
\text { support } \\
\text { essential } \\
\text { Challenges in } \\
\text { mastering } \\
\text { competencies in } \\
\text { a collaborative } \\
\text { environment }\end{array}$ \\
\hline $\begin{array}{l}\text { Holtkamp and } \\
\text { Pawlowski } \\
\text { (2015), Poland }\end{array}$ & $\begin{array}{l}\text { Global software } \\
\text { development } \\
\text { process }\end{array}$ & $\begin{array}{l}\text { Literature } \\
\text { review }\end{array}$ & $\begin{array}{l}\text { Identify } \\
\text { challenges, } \\
\text { processes, \& } \\
\text { competencies }\end{array}$ & $\begin{array}{l}\text { Majority of } \\
\text { challenges in } \\
\text { project plann ing } \\
\text { and execution } \\
\text { stage }\end{array}$ \\
\hline $\begin{array}{l}\text { Ivashova, Dub, } \\
\text { Kenina, } \\
\text { Kosinteseva, \& } \\
\text { Migatcheva } \\
\text { (2016): Russia }\end{array}$ & $\begin{array}{l}\text { Competencies of } \\
\text { Russian } \\
\text { engineering } \\
\text { students }\end{array}$ & $\begin{array}{l}\text { Survey of } \\
\text { industry experts }\end{array}$ & $\begin{array}{l}\text { Competencies in } \\
\text { projects }\end{array}$ & $\begin{array}{l}\text { Technical skills } \\
\text { and improving } \\
\text { practical } \\
\text { component are } \\
\text { most important }\end{array}$ \\
\hline $\begin{array}{l}\text { Manwadu \& } \\
\text { Johar (2016): Sri } \\
\text { Lanka }\end{array}$ & $\begin{array}{l}\text { Competencies of } \\
\text { Sri Lankan } \\
\text { software } \\
\text { engineers }\end{array}$ & $\begin{array}{l}\text { Survey of } \\
\text { industry experts }\end{array}$ & $\begin{array}{l}\text { Identify } \\
\text { competencies }\end{array}$ & $\begin{array}{l}\text { Lack technical } \\
\text { skills; need soft } \\
\text { skills }\end{array}$ \\
\hline
\end{tabular}

the host country, if they had the appropriate technical knowledge and cross-cultural communication skills, they succeeded most of the time.

These findings are also helpful to the host institutions that sponsor such travel and projects. They can use these results in choosing those candidates who are most likely to succeed in their projects and arrange appropriate cross-cultural communication training for their participants.

Engineers and professionals frequently have limited preparation for undertaking international projects. When they do so, the findings might be helpful to them in preparing for such assignments by honing their engineering/ technical skills so that their foreign counterpart treats them with respect and trusts them to work together to complete the projects. Jesiek et al. (2014) report on three specific contextual dimensions of global engineering preparedness that include technical coordination, understanding and negotiating engineering cultures, and navigating ethics, standards, and regulations. We saw examples of this in action when U.S. students who were able to display preparedness to their Indian counterparts earned respect and were provided access to critical documents; whereas, those who did not show preparedness were sidelined and ignored during the project. The findings imply that students and engineers who plan to work internationally need to first prepare themselves to be conversant with the technologies involved in the project, and then be able to communicate well with their counterparts so that they trust each other in order to identify the problems, design appropriate responses, pick a solution, and then implement it. A third-party facilitator to help with day-to-day activities is critical in ensuring success of such projects. 


\section{LIMITATIONS AND FUTURE RESEARCH}

The major limitation of this study is that the context of the project influences the outcomes as shown by the results of studying of four other projects (Table 5) using the Realist Synthesis methodology. Emphasizing the importance of context, Brocke and Lippe (2015) point out that collaborative research projects are comprised of highly heterogeneous activities and managerial conditions that often make it necessary to alter managerial and organizational practices during the project life-cycle, as "the situation-specific circumstances of inter-disciplinary research are important determinants of success or failure and that it is, therefore, difficult to generalize rules for effective management" (Konig, Diehl, Tscherning, \& Helming, 2013). Therefore, even though we have come up with a list of competencies that are important through analyzing these 22 projects, these findings cannot be generalized, are specific to the context of this project, and limited to engineering/ technology students. Other international projects may require competencies that are not addressed in this paper. In the future, it is possible to conduct other studies that examine the competencies required of students in non-engineering disciplines (Ballesteros-Sanchez, Ortiz-Marcos, \& Rodriguez-Rivero, 2019).

All the projects studied in this paper used the water-fall methodology of project management; the results might be different if they used the agile methodology. Factors such as the human factors involved in the interactions between the U.S. and Indian students and the emotional intelligence exhibited by them might have also biased the results (Boyatzis et al., 2002; Wiek et al., 2011).

If the participants in the international projects were experienced employees who were conversant with the context of the projects, the required competencies might differ significantly from what we had identified in this research (Verma, 1996; Barker, 2014; Marsino, 2013). A future research topic is to study the required competencies of experienced personnel in undertaking international projects.

The study used a longitudinal case study approach to come up with these findings. In the future, it may be possible to develop these further by creating a research model and questionnaire that can be administered to the students who travel on such projects, leading to more robust results. It would also be interesting to provide pre and post surveys to the students embarking on international projects and compare the results; a further comparison with students who do not travel might also provide an interesting measure of the potential benefits students gain as a result of engaging in international projects.

This article incorporates the competencies proposed by Levonisova et al., (2014) in the flow chart. Instruments to measure Engineering Global Preparedness have been created by Streiner, McCave, Levonisova, Savage \& Besterfield-Sacre (2015) and Rezende and Blackwell (2019). It is possible to use such instruments to evaluate how well students are prepared to work in international projects in the future. Such a quantitative study would be an interesting future research and add to the theoretical framework on this topic.

\section{CONCLUSION}

Engineering students are expected to develop competencies so that they can be well prepared to work in the globally connected world. This article provides the results of a research based on twenty-two international projects that were conducted by U.S. students in India. We found that the student's lack of awareness of the other country was not an impediment as far as they had the help of a third-party facilitator to function in India. They needed to have the requisite technical skills to conduct the project. In addition, successful projects showed instances when the students were willing to adapt to the country and develop appropriate cross-cultural communication skills and strategies to work with their Indian counterparts. Such students secured the trust of their international partner(s) leading to successfully identifying the problem, analyzing alternatives, and solving the problems presented in each of the projects. 


\section{ACKNOWLEDGMENT}

This paper is based upon work supported by the National Science Foundation under Grants No. 0966561 and 0623351. Any opinions, findings, and conclusions or recommendations expressed in this material are those of the author and do not necessarily reflect the views of the National Science Foundation. 


\section{REFERENCES}

Ballesteros-Sanchez, L., Ortiz-Marcos, I., \& Rodríguez-Rivero, R. (2019). The Impact of Executive Coaching on Project Managers' Personal Competencies. Project Management Journal, 50(3), 306-321. doi: $10.1177 / 8756972819832191$

Barker, S. (2014). Brilliant Project Management (2nd ed.). Trans-Atlantic Publications.

Bartel-Radic, A., Moos, J. C., \& Long, S. K. (2015). Cross-cultural management learning through innovative pedagogy: An exploratory study of globally distributed student teams. Decision Sciences Journal of Innovative Education, 13(4), 539-562. doi:10.1111/dsji.12076

Bechtel, S. D. (2006). Challenges for engineers. The Bent of Tau Beta Pi, 12.

Boyatzis, R. E. (1982). The competent manager: A model for effective performance. New York: John Wiley \& Sons.

Boyatzis, R. E. (1996). Consequences and rejuvenation of competency-based human resource and organization development. Research in Organizational Change and Development, 9, 101-122.

Boyatzis, R. E., Stubbs, E. C., \& Taylor, S. N. (2002). Learning cognitive and emotional intelligence competencies through graduate management education. Academy of Management Learning \& Education, 1(2), 150-162. doi:10.5465/amle.2002.8509345

Brière, S., Proulx, D., Flores, O. N., \& Laporte, M. (2015). Competencies of project managers in international NGOs: Perceptions of practitioners. International Journal of Project Management, 33(1), 116-125. doi:10.1016/j. ijproman.2014.04.010

Brocke, J. V., \& Lippe, S. (2015). Managing collaborative research projects: A synthesis of project management literature and directives for future research. International Journal of Project Management, 33(5), 1022-1039. doi:10.1016/j.ijproman.2015.02.001

Collyer, S. (2017). Culture, Communication, and Leaderships for Projects in Dynamic Environments. Project Management Journal, 47(6), 111-125. doi:10.1177/875697281604700608

Daniels, M., Cajander, Å., Clear, T., \& McDermott, R. (2015). Collaborative technologies in global engineering: New competencies and challenges. International Journal of Engineering Education, 31(1), 267-281.

de Rezende, L. B., \& Blackwell, P. (2019). Project management competency framework. Iberoamerican Journal of Project Management, 10(1), 34-59.

Dillon, S., \& Taylor, H. (2015). Employing Ground Theory to Uncover Behavioral Competencies of Information Technology Project Managers. Project Management Journal, 46(4), 90-104. doi:10.1002/pmj.21511

Dotsenko, N., Chumachenko, D., \& Chumachenko, I. (2019). Modeling of the process of critical competencies management in the multi-project environment. In Proceedings of the 2019 IEEE 14th International Conference on Computer Sciences and Information Technologies (CSIT) (pp. 89-93). IEEE Press. doi:10.1109/STCCSIT.2019.8929765

Eskerod, P. (2010). Action learning for further developing project management competencies: A case study from an engineering consultancy company. International Journal of Project Management, 28(4), 352-360. doi:10.1016/j.ijproman.2010.01.010

Gough, D., Oliver, S., \& Thomas, J. (2012). An Introduction to Systematic Reviews. London: Sage Publications Ltd. Hager,P., \& Gonczi, A. (1996). What is competence? MedicalTeacher, 18(1), 15-18. doi:10.3109/01421599609040255

Holtkamp, P. \& Pawlowski, J.M. (2015). A Competency-Based View on the Global Software Development Process. Journal of Universal Computer Science, 21(11), 1385-1404.

Ivashova, V. A., Dub, G. V., Kenina, D. S., Kosintseva, Y. F., \& Migatcheva, M. V. (2016). Actualization of Competencies of Graduates-Engineers in Russia. International Journal of Environmental and Science Education, 11(12), 5311-5319.

Jesiek, B. K., Zhu, Q.; Woo, S.E.; Thompson, J. \& Mazzurco, A. (2014). Global Engineering Competency in Context: Situations and Behaviors Global. Online Journal for Global Engineering Education, 8(1). 
Konig, B., Diehl, K., Tscherning, K., \& Helming, K. (2013). A framework for structuring interdisciplinary research management. Research Policy, 42(1), 261-272. doi:10.1016/j.respol.2012.05.006

Levonisova, S., Huang, S., Streiner, S., Cunningham, S., Ragusa, G., Besterfield-Sacre, M., \& Matherly, C. (2014, June). Moving toward a research informed conceptual model of engineering global preparedness. Presented at the 2014 ASEE Annual Conference and Exposition. Academic Press.

Lewicki, R. J., Weiss, S. E., \& Lewin, D. (1992). Models of conflict, negotiation and third-party intervention: A review and synthesis. Journal of Organizational Behavior, 13(3), 209-252. doi:10.1002/job.4030130303

Löhr, K., Graef, F., Bonatti, M., Mahoo, H. F., Wambura, J., \& Sieber, S. (2017). Conflict management systems for large scientific research projects. International Journal of Conflict Management, 28(3), 322-345. doi:10.1108/ IJCMA-04-2016-0022

Lutz, W., Butz, W. P., \& Samir, K. E. (Eds.). (2017). World population \& human capital in the twenty-first century: An overview. Oxford University Press.

Manawadu, C. D., \& Johar, G. M. (2016). Measuring the Software Engineering Competencies: A Sri Lankan Software Industry Perspective. Asian Journal of Social Sciences and Humanities, 5(2), 101-108.

Marsino, A. (2013). Emotional Intelligence for Project Managers: The People Skills You Need to Achieve Outstanding Results. Amacom.

National Science Foundation. (2015). International research experiences for students. Retrieved from https:// www.nsf.gov/funding/pgm_summ.jsp?pims_id=12831\&org=NSF\&sel_org=NSFW\&from=fund

Ojiako, U., Chipulu, M., Marshall, A., Ashleigh, M. J., \& Williams, T. (2015). Project management learning: A comparative study between engineering students' experiences in South Africa and the United Kingdom. Project Management Journal, 46(4), 47-62. doi:10.1002/pmj.21510

Ortiz-Marcos, I., Cobo Benita, J. R., Aldeanueva, C. M., \& Colsa, Á. U. (2013). Competency training for managing international cooperation engineering projects. Project Management Journal, 44(2), 88-97. doi:10.1002/ pmj. 21328

Pawson, R. (2006). Evidence-Based Policy: A Realist Perspective. London: Sage Publications Ltd. doi:10.4135/9781849209120

PMBOK Guide—Seventh Edition. (2017). Project Management Institute. Retrieved from https://www.pmi.org/ pmbok-guide-standards/foundational/pmbok

Sankar, C. S., Raju, P. K., \& Clayton, H. (2009). Preparing students for global research experiences: U.S.-India summer projects. International Journal of Engineering Education, 25(5), 1046-1058.

Schoper, Y., Gemunden, H. G., \& Nguyen, N. N. (2016). Fifteen Future Trends for Project Management in 2025. In H. Knoepfel and J. Martinez-Almela (Eds.), Future Trends in Project, Programme, and Portfolio Management, 2016, Proceedings of the International IPMA Expert Seminar in Zurich (pp. 23-43). Academic Press.

Streiner, S. C., McCave, E., Levonisova, S. V., Savage, R. E., \& Besterfield-Sacre, M. E. (2015). An Inductive Qualitative Analysis of Student Interviews on Engineering Global Preparedness. age, 26.

Sutcliffe, N., Chan, S. S., \& Nakayama, M. (2020). A Competency Based MSIS Curriculum. Journal of Information Systems Education, 16(3).

Tjosvold, D., Wan, P., \& Tang, M. (2016). Conflict-Positive Organizations: Applying Mediation and Conflict Management Research. In Advancing Workplace Mediation Through Integration of Theory and Practice (pp. 219-230). Springer International Publishing.

Verma, V. (1996). Human Resource Skills for Project Managers (Human Aspects of Project Management, Volume Two). Project Management Institute.

Wiek, A., Withycombe, L., \& Redman, C. L. (2011). Key competencies in sustainability: A reference framework for academic program development. Sustainability Science, 6(2), 203-218. doi:10.1007/s11625-011-0132-6 
International Journal of Project Management and Productivity Assessment Volume $9 \cdot$ Issue $2 \cdot$ April-June 2021

\section{APPENDIX}

Table 6. Analysis of each project based on required competencies

\begin{tabular}{|c|c|c|c|c|c|}
\hline Project & $\begin{array}{l}\text { International } \\
\text { Contextual } \\
\text { Knowledge }\end{array}$ & $\begin{array}{l}\text { Global } \\
\text { Engineering } \\
\text { Preparedness }\end{array}$ & $\begin{array}{l}\text { Personal and } \\
\text { Professional } \\
\text { Qualities }\end{array}$ & $\begin{array}{l}\text { Cross-Cultural } \\
\text { Communication } \\
\text { Skills \& } \\
\text { Strategies }\end{array}$ & $\begin{array}{l}\text { Sponsor's } \\
\text { Assessment } \\
\text { of the Project }\end{array}$ \\
\hline $\begin{array}{l}\text { 1. Data } \\
\text { Synchronization } \\
\text { Project }\end{array}$ & Low & High & High & Low & Sucœess \\
\hline $\begin{array}{l}\text { 2. Thermal Comfort } \\
\text { Project - I }\end{array}$ & Low & Medium & Medium & Low & Fail \\
\hline $\begin{array}{l}\text { 3. Thermal Comfort } \\
\text { Project }-\|\end{array}$ & Low & High & High & Low & Sucœess \\
\hline $\begin{array}{l}\text { 4. Thermal Comfort } \\
\text { Project - III }\end{array}$ & Low & High & High & Low & Success \\
\hline $\begin{array}{l}\text { 5. Thermal Comfort } \\
\text { Project - IV }\end{array}$ & Medium & High & High & Medium & Success \\
\hline $\begin{array}{l}\text { 6. Thermal Comfort } \\
\text { Project }-V\end{array}$ & High & High & High & Medium & Success \\
\hline $\begin{array}{l}\text { 7. Design of } \\
\text { Buildings }-1\end{array}$ & Low & High & High & Medium & Sucœess \\
\hline $\begin{array}{l}\text { 8. Design of } \\
\text { Buildings }-\|\end{array}$ & Low & Medium & Medium & Medium & Sucœess \\
\hline $\begin{array}{l}\text { 9. Auditorium } \\
\text { Acoustic Reflector } \\
\text { Design }\end{array}$ & Low & High & High & Medium & Success \\
\hline $\begin{array}{l}\text { 10. Development of } \\
\text { Life Cycle Cost } \\
\text { System }\end{array}$ & Medium & Medium & High & Medium & Fail \\
\hline $\begin{array}{l}\text { 11. Non-destructive } \\
\text { testing of oil tanks }\end{array}$ & Low & High & High & Low & Success \\
\hline $\begin{array}{l}\text { 12. Automated weld } \\
\text { inspection }\end{array}$ & High & Medium & High & Medium & Sucœess \\
\hline $\begin{array}{l}\text { 13. Laser ultras onics } \\
-1\end{array}$ & Low & Medium & High & LoW & Success \\
\hline $\begin{array}{l}\text { 14. Laser } \\
\text { Uttrasonics - II }\end{array}$ & Medium & Medium & Low & Low & Fail \\
\hline $\begin{array}{l}\text { 15. Developing an } \\
\text { impact echo } \\
\text { prototype }\end{array}$ & Low & High & High & Medium & Success \\
\hline $\begin{array}{l}\text { 16. Solar panel } \\
\text { design }\end{array}$ & Low & Medium & High & Medium & Success \\
\hline 17. Handbag design & Low & High & High & Low & Success \\
\hline $\begin{array}{l}\text { 18. Design of } \\
\text { aut omated } \\
\text { inspection trolley }\end{array}$ & Low & Medium & High & Low & Success \\
\hline $\begin{array}{l}\text { 19. Develop a cross- } \\
\text { cultural } \\
\text { communication } \\
\text { game }\end{array}$ & Medium & Medium & High & Low & Fail \\
\hline $\begin{array}{l}\text { 20. Develop an } \\
\text { Accounting IS }\end{array}$ & Low & High & High & Low & Success \\
\hline $\begin{array}{l}21 \text {. Develop a } \\
\text { business plan }\end{array}$ & Low & Low & Medium & Low & Fail \\
\hline $\begin{array}{l}\text { 22. Document a } \\
\text { telemedicine system }\end{array}$ & Low & High & High & Medium & Sucœess \\
\hline
\end{tabular}

Chetan S. Sankar is the Emeritus professor of Information Systems, Auburn University. He holds a Bachelor's in Engineering from NIT Trichy, PGDM from Indian Institute of Management, Calcutta, and a PhD from the Wharton School of Business, University of Pennsylvania. His teaching and research interests are on project management and instructional pedagogies. He enjoys playing with his grandchildren and learning from them about the meaning of life. 